\title{
Green Energy: Examining Their Effects on Heritage Sites and Climate Change Mitigation
}

\author{
Mehdi S. Kaddory Al-Zubaidy \\ Energetic Setup Sdn Bhd, Architecture Consultancy, Kuala Lumpur, Malaysia \\ Email: mkaddory@yahoo.com
}

Received 21 January 2015; accepted 9 February 2015; published 10 February 2015

Copyright (C) 2015 by author and Scientific Research Publishing Inc.

This work is licensed under the Creative Commons Attribution International License (CC BY).

http://creativecommons.org/licenses/by/4.0/

(c) (i) Open Access

\begin{abstract}
The damage which is brought about by global warming and climate change to heritage sites is more or less immutable. However, further deterioration could be slowed, if not stopped, with the patronization of green energy. Three sources of green energy, namely solar power, wind power, and hydropower were discussed in this research. Their indirect roles in preserving heritage sites were examined and their cumulative effects on mitigating climate change were also cited. Results showed that the climate might have been continually changing for the past thousands of years. The effects of climate change and global warming on the arctic ice, carbon dioxide concentration, sea levels, global surface temperature and land ice status were undeniable. These factors greatly contributed to the deterioration of the preservation of world heritage sites.
\end{abstract}

\section{Keywords}

Green Energy, Climate Change, Renewable Energy Sources, World Heritage Site (WHS), Climate Change Mitigation, Global Warming

\section{Introduction}

Awareness about the increasing impact of climate change on natural and cultural aspects has not been highlighted until in 2005 where a number of pro-conservation sectors approached the World Heritage Committee to attend to several issues that generally threaten the conservation of heritage sites [1]. Today, as being one of the most challenging tasks the world faces [2], UNESCO World Heritage Centre (2008) also elaborates that climate change has not only affected both natural and cultural heritage sites, but has also hewed great impacts on the sociocultural aspects of the world's ecosystems [1]. 
As cited by the Intergovernmental Panel on Climate Change [3], the National Snow and Data Center have given out an extensive definition of climate change as the varying constancies in climatic properties with regard to statistical measurements over a period of time, with no regard to whatever the cause is. Although climate change can also be attributed to natural processes that the Earth eventually undergoes, the United Nations Framework Convention on Climate Change [4], however, recognizes that human acts hold responsible, be it directly or indirectly, for whatever change the climate submits to in a specified period. Considering the context of environmental policy, the term "climate change" could be limited to anthropogenic impact on the environment or the human impact on global warming. The National Aeronautics and Space Administration [5], nonetheless, swerve from this context limitation. Global warming is the cumulative increase in the global surface temperature, on the other hand, climate change is a much greater term encompassing global warming in itself and all the other environment alterations that are affected by the increase in environmental greenhouse gases [5]. Moreover, global warming could be considered as a worldwide phenomenon. However, the effects of climate change tend to be specific to the point that different places in the globe might have different climate changes brought about by global warming itself. This not only affects livelihood, but also cultures and biodiversities [6].

The term "climate change" will be used throughout the paper in order to widen the scope of the study and not limit the discussion into global warming solely as well. Contrary to popular belief, climate change does not only embody anthropogenic contributions, but it has also its origins coming from innate Earth processes such as external and internal forcing [7]. External forcing could be differentiated from internal forcing by referring to the former as factors that are concerned with the orbital locations of the Earth that affect the amount of solar energy it receives; internal forcing, on the other side, are phenomena that occur with the Earth. Beniston [7] enumerated these internal forcing as volcanic eruptions, ocean-atmosphere feedbacks, alterations in marine and terrestrial biospheres, and natural mechanisms in the Cryosphere [7].

However, it is conspicuous that human acts cannot waive any responsibility in the initiation and progress of global warming. This is an important aspect to address since numerous human activities do not only contribute to the greater build-up of greenhouse gases by emission of carbon dioxide [8]. They also impact the global environment through fishing, being involved in livestock sector, energy industry, production of pesticides, mining. Among all these, the transport sector does not only prove to be the largest contributor to emissions of gases in the environment, but has also the greatest liability on the global warming [8].

The Intergovernmental Panel on Climate Change [3] raises awareness by explaining that increasing temperature deserts might lead to widespread desertification after desert species reach their tolerance limits of heat. Furthermore, UNESCO World Heritage Centre [1] states that climate change alters the security of the preservation of heritage sites because its being immanent promotes the growth of pests and pathogens and even encourages fires. The melting of glaciers evidently affects the global hydrological status and the increased incidence in coral bleaching will have an imminent influence on these reefs' future production [3].

On a specific note, Tamwoy [9] has exposed in her study the threat climate change has brought in the maintenance of their Australian heritage sites such as the Great Barrier Reef and the Wet Tropical Rainforests [9]. Continuous bleaching of coral reefs will eventually result in their death, leaving hundreds of fish species without a natural habitat. Some of the changes being experienced by the continent of Africa are rising in temperature about $1^{\circ} \mathrm{C}$, the lessening of cold days and the frequent heat waves, and the unequal distribution of rainfall in its northwest, east and southwest regions [10].

In its call for help to preserve its inscribed heritage sites, UNESCO World Heritage Centre [11] mentioned the melting glaciers of the Antarctic as one of the major effects of climate change. Aside from being stripped of their inscribed beauty, these sites affected by increase temperature also disrupt the natural habitat of the rare species of snow leopard that is found in the Samargatha National Park in Nepal. By the year 2100, it is also predicted that $58 \%$ of the world's coral reefs and the thousands of fish species that live within them will be affected by rising temperature in an extensive degree. Since 1800s, the average temperature of the Earth's surface has increased to 0.74 degrees C [3]. By 2099, it is expected to reach its maximum increase, which is $6.4^{\circ} \mathrm{C}$ [3].

With the increasing threats to further deterioration, it is a significant step to patronize green energy or the renewable sources to run the present and the foreseeable culture of the global environment. One of the main types of renewable energy is a biofuel which is a product of carbon fixation [12]. Despite the claim of European Environment Agency (2009) that biofuels are unhelpful to global warming, increase in usage of green energy could be evident by the widespread utilization of hydroelectricity [13], which is proven to emit lesser carbon dioxide than fossil fuels do. The wind power industry is also becoming more prominent, paving the way for an annual 
growth rate of $20 \%$. The renewable energy that comes from solar plants prove to be unstoppable as well, since records show that solar power plants have been providing continuous flow of dependable green energy since 1984 [14]. Albeit geothermal power sources are installed in a great extent in the California geysers, countries that exhibit largest capacity for this renewable source include the United States, Philippines and also Indonesia [15]. Energy coming from geothermal power plants is highly green energy because the heat being given off is much lesser than what the Earth contains. For the next 25 years, it is projected that the use of electricity coming from hydroelectric power will increase around $3 \%$ for each year. For producing about $16 \%$ of the total global electricity generation, hydroelectricity is considered as the most popular and conveniently used form of renewable energy [13].

The damage brought about by global warming and climate change to heritage sites is more or less immutable. However, further deterioration could be slowed, if not stopped, with the patronization of green energy.

In order to abide by the goals of this study, three sources of green energy, namely solar power, wind power and hydropower were discussed in this research. Their indirect roles in preserving heritage sites were examined and their cumulative effects on mitigating climate change were also cited.

The goal of this research is to give a general overview on what these three sources could contribute in order to abate the progressing of the greenhouse effect that in turn, fuels the advancement of global warming. World Heritage Sites, together with the Biosystems that surround those, will be greatly affected by the worsening problem of climate change. However, proper education through the dissemination of papers of this sort will provide a channel in spreading knowledge about the numerous benefits of shifting to green energy.

\section{Statement of the Problem}

Generally, this study aims to examine the effects of solar power, wind power, and hydropower on heritage sites preservation and climate change mitigation.

Specifically, the concerns of the study are:

1) What is the current status of the Earth under climate change and global warming?

2) What are the trends of the green energy sources with regards to:

a) Solar power;

b) Wind power;

c) Hydropower?

3) What are the environmental effects of these renewable sources?

4) What is the most efficient renewable energy source?

5) Is there a significant relationship between the use of renewable energy sources (e.g. solar power, wind power, and hydropower) and the preservation of world heritage sites?

\section{Hypothesis of the Study}

There is no significant relationship between the use of renewable energy sources (e.g. solar power, wind power, and hydropower) and the preservation of world heritage sites.

The main area of this research paper is to examine objectively whether there is a relationship between the use of renewable energy sources and the preservation of heritage sites and climate change mitigation. In light of these variables, the methodology of the paper will only concern itself with the gathering of data from reliable sources such as books, journals, officially published research papers, news articles, and acknowledge organizational reports, both local and foreign. This research paper is both limited by two designs: qualitative-case design and quantitative-correctional-descriptive design.

\section{Climate Change}

The Environmental Protection Agency [16] gave a simple elaboration of climate change, not only defining it as a significant change in the mechanisms of a current climate over time, but also a change that alters greatly the natural processes of temperature, rainfall or precipitation, and wind patterns that take place at least a decade. The National Aeronautics and Space Administration [5] also give an overview of the current status of the Earth while giving statistics on climate change. The artic sea ice minimum has decreased by $12 \%$ per decade, the carbon dioxide has elevated to 393 parts per million (PPM), the sea level, gaining $3.19 \mathrm{~mm}$ per year, the global 
temperature has increased its average to $1.5 \mathrm{~F}$ since 1880, and the Greenland ice has thinned menacingly 100 billion tons per year [5].

In the introduction, it was discussed that climate change is also brought about by natural processes that the Earth undergoes over time [7]. However, the anthropogenic contributions to global warming are undeniable, making those the greatest channel for various climate changes in specific areas of the world. However, Beniston [7] has given emphasis on the Earth's mechanisms that are also responsible for climate change, referring to those as external and internal forcing.

\subsection{Evidences of Climate Change}

Seiz and Foppa [17] claimed in their report that the easiest way to find an indication about the current climate change status of the Earth is to take a look at the glaciers. Dyurgerov and Meier [18] described systematic measurements of glaciers and recorded that their cumulative thickness change had been in a steady decline since the 1960's.

National Aeronautics and Space Administration [5] also point out that another indicator to look at, to assess the climate change is the arctic sea ice loss. The National Snow and Ice Data Center [19] also gives out information that since 1979 up to the year 2000, the decline rate of arctic sea ice has reached $11.5 \%$ per decade.

The indicator that scientists commonly use to assess the climate change status is the precipitation, with past records having been retrieved through ice cores, sediments in marine systems, and even tree rings [20]. Evidently, climatic changes affect precipitation, for polar desserts with low precipitation used to exist on Earth 18,000 years ago [21], but in the same study, the authors affirm that the world has higher precipitation rate now compared 8000 years ago.

Vegetation is also a factor that is greatly affected by climate change. This affectation was demonstrated by Carboniferous Rainforest Collapse 305 million years ago where thousands of vegetation species went extinct due to sudden climate change. In the current stage, the same mechanisms (i.e., larger and faster changes in the climate) could lead in widespread desertification especially in areas where animals have reached their heat tolerance limit.

\subsection{World Heritage Sites}

The World Heritage Committee convened and had been straight about the issue "that the impacts of climate change are affecting many and are likely to affect many more World Heritage properties, both natural and cultural, in the years to come" [12], recognizes that the planet is continuously changing. However, they also assert that humans are likely to be directly responsible of the climate change issues that the world is facing now.

In their published report Case Studies on Climate Change and World Heritage, World Heritage Centre [1] exposed several impacts of climate change on numerous heritage sites that are in glacier, marine, terrestrial, archaeological, and historic sites.

One of the sites which are highly affected is the Samargatha National Park in Nepal, a home of the rare species, snow leopard. Among the effects of climate change, the most prominent is the glacial lake outburst floods and the limited water supply that may be imposed by shortage of fresh water supply from the glaciers. If the glaciers continue to melt, it is unlikely that the winter snow will be able to compensate for the lost ice [1].

The Great Barrier Reef in Australia also exhibits the tragic effects of climate change on World Heritage Sites. Aside from the continuous coral bleaching that is brought about by the rise of surface temperature, the progressive deterioration of coral reefs may result in the loss of habitat of thousands of fish species and may pose threat to the tourism sector of the country. UNESCO World Heritage Centre [1] further explains that the marine biodiversity in the area is also highly compromised. With the affectation of marine biodiversity in the area, the yields of the fishing industry will not only tap on the area's marine ecosystem, but also on the local population that depends on that kind of livelihood [3]. There is also an established correlation done by Heogh-Guldberg [22] between El Niño-Southern Oscillation (ENSO) and the negative state of marine mammals, turtles and seabird species. The Intergovernmental Panel on Climate Change [3] also considered the 58\% global scale of coral reefs to be at risk not only from the natural phenomena such as storms, but also to human activities that include, but not limited to urbanization, tourism, coral mining, superfluous fishing, pollution on sewage, and sedimentation on marine ecosystems.

Adams and Faure [21] exposed in their study that there was an increase in precipitation in the last years, and 
Thames River, which flows through London, could be a perfect evidence of climate change. The change in climate predisposes the more frequent flooding in the River Thames [23], and apparently, $2.2 \mathrm{~mm}$ has been observed in the 20th century at Sheerness [12]. The Policy Document on Climate Change by UNESCO also admittedly reports that historic establishments may have materials that are more porous than the modern ones, and any increase in soil moisture might put them all at risk for further deterioration. Additionally, flooding may cause more damage on historic buildings that were not meant to withstand such occasions [12].

\subsection{Renewable Energy Sources}

Commonly coined as "green energy", it is a renewable energy produced from natural sources that include geothermal heat, rain, wind, sunlight, and even tides and waves. The utilization of green energy as an answer to the growing problem on global warming and climate change has become mainstream for the reasons that it can replace traditional energy sources when it comes to power generation, space heating, and transport fuels [24].

The use of renewable energy sources as an alternative energy source is a part of the climate change mitigation strategy being imposed by many countries today [25]. Traditional energy source such as coal promotes the expansion of greenhouse gases in the atmosphere. However, the use of renewable energy decreases the concentrations of these gases and thereby lessening the harmful effects of global warming [26].

The United Nations could not emphasize it more when it defined climate change mitigation involved the expansion of forests to reduce atmospheric carbon dioxide, improvement of building insulation, and switching to renewable energy sources such as wind power or solar energy [4]. The Stern Review, on the other hand, generally identified measures that could help in mitigating climatic changes such as increasing efficiency of energy sources, further utilization of low-carbon innovations, lessening carbon-intensive goods and decreasing emissions of fossil fuels [27].

The numerous movements and policies concerning the preference of renewable energy sources compared to natural ones are attributed to the widespread scientific opinion on climate change and the conspicuous threat it possesses. Apparently, the measures being taken with regards to global warming and climate change are not concerned with the reversibility of the problems, but to only halt its progress.

\subsubsection{Solar Energy}

The method of converting energy coming from sunlight into electricity could be done in two ways: photovoltaic and concentrating solar power [28].

One of the main uses of solar energy is electric production, which only came to boom in 2012 due to high installation costs in the previous years. Although due to the advancements brought by technology aside from increased demand, the increased sophistication in manufacturing also brought the costs that are subject to photovoltaic installation [28]. A high economic factor was also invested in solar energy since photovoltaic (PV) systems could reproduce themselves as much as 34 times before retiring in 10 - 30 years. This means that the energy PV systems give out are worth the investment of any sector.

Despite the contribution it is regarding mitigating the effects of climate change; there are still some environmental issues that need to be tackled when it comes to the consumption of solar energy. Although solar power does not bring any harmful environmental effects when operated, the process of its production, however, does [3]. The use of cadmium in PV films is one of the issues being raised, since this element frequently deposits in many ecosystem food chains [28].

\subsubsection{Wind Power}

Much of wind power is used to convert wind energy into readily available advantages such as running turbines to produce electricity, windmills of mechanical works and wind pumps for drainage, propelling as for ships, and water pumping [29].

The use of wind power displays a promising growth trend, since in 2010, almost half of the global wind power installations occurred outside from the traditional market of Europe and North America. The wind energy sector was affected by the recent global crisis. However, starting 2008, its growth averaged to $27.6 \%$ each year and was projected to increase to $15.7 \%$ by 2013 [30].

Similar to solar power which only depends on the solar energy, wind energy resource is also highly dependent on wind, which has a very variable speed. However, wind forecasts are available in large areas, making wind as 
a predictable energy source [31].

Unlike fossil fuels and other traditional energy sources, wind power has minimal effects on the environment, considering that it does not necessitate the consumption of fuel and does not contribute to air pollution as well. The probable main disadvantage of wind power is the large requirement for land space. However, agricultural sites can be considered. The mortality of birds and bats are also addressed around the turbines, but the effect of this occurrence is unpredictable as far as ecosystems are concerned [32].

There is a high public acceptance of wind power across Europe, as shown by the public polls given out by private sectors. A study shows that $80 \%$ of Europeans are in favor of wind power utilization [33].

\subsubsection{Hydroelectricity}

The main product of hydropower is hydroelectricity, the type of electricity that is produced when the electrical power that is utilized has been garnered from the falling water through the use of the gravitational force [34]. The World Watch Institute [14] reports that hydroelectricity is the most widely used form or renewable energy, having been the source of $16 \%$ of global electricity production in 2010 .

Aside from being renewable, the benefit of using hydroelectricity is much welcomed due to its numerous generation methods. Hydroelectric power could be generated through conventional dams [35], the pump-storage, river, and even through tide power.

Although hydroelectricity is praised because of its low production cost, several effects on the environment are being addressed with its existence. Environmentalists are concerned about the fact that the large land required for the operation of this renewable source tends to give way to the submersion of the rich biodiversities that include grasslands and riverine valley forests [36].

Siltation is also a major discussion with regards to its disadvantages for build-up of too much sediment causing the reservoirs to fail during floods [37]. Reservoirs of some region are also found to emit methane, a greenhouse gas [38]. Another inconvenience that is brought about building dams and reservoirs for hydroelectric power is the relocation of the people who live in the area. In the year 2008, it is estimated that around 80 million people have been affected by the build-up of dams worldwide [38].

Hydroelectric power plants, however, are more predictable than wind farms when it comes to load factor [39]. Similar to other renewable energy source, hydropower limits as well the emission of carbon dioxide in the atmosphere.

\section{Research Design}

The research designs used in the study were case-study and correlations-descriptive study designs. On the first part, this research paper was in case-study approach since objective research was done about two topics: renewable energy sources and world heritage sites [40]. An objective conclusion was drawn based from these researches at the end of the study. Bromley had given an explanation of how a case study was done by stating that it was a "systematic inquiry into an event or a set of related events which aims to describe and explain the phenomenon of interest" [41].

On the second part, correlational-descriptive design was used in order to answer Problem 4 of the research paper.

This study is also multivariate research for there were two variables involved: the renewable energy sources that include solar power, wind power and hydropower, the heritage sites preservation. The variables were described. They were also investigated in an in-depth manner.

\subsection{Locale and Population of the Study}

The study was to be conducted in three selected sites. The population of this study was composed of 93 environmental-science related professionals.

\subsection{Description of the Respondents}

The body of data was gathered from 93 respondents who were knowledgeable with the sciences of climate change and global warming. These individuals were also updated regarding the current status of the World Heritage Sites due to global climate change. A purposive sampling technique was done in the selection of the respondents. 


\subsection{Instrumentation}

In order to establish the results of the study, a pen-and-paper questionnaire was utilized in gathering data from the respondents. The questionnaire was divided into two parts:

Part I-The Profile of the Respondents;

Part II-Miscellaneous Assessment of the Relationship between the Use of Renewable Energy Sources and the Preservation of Heritage Sites.

\subsection{Data Gathering}

Much of the data gathering of this research was done through the use of the Internet by gaining access to reliable journal sources such as Science Direct and Elsevier. Reports coming from UNESCO World Heritage Committee also provided an ample amount of information for this research to be completed. The Case Studies on Climate Change and World Heritage [12], for instance, exposed various world heritage sites that were affected by climate change. The World Heritage Convention [1] also released a policy regarding the impacts of climate change on heritage sites, and from those cases, several climate change mitigation measures that include the use of renewable energy were found. Nonetheless, in order to answer Problem 4 of this research study, a survey was done among 93 professionals who were acquainted with environmental science and climate change mitigation.

\section{Results and Discussion}

This section deals with the presentation, analysis and interpretation of data that are concerned with the questions presented in this study.

The discussion divided into four parts: the current status of the Earth under the climate change and global warming; the trends of green energy sources such as solar power, wind power, and hydropower; the environmental effects of solar power, wind power, and hydropower; and the presentation of efficiency scales among solar power, wind power, and hydropower.

The sequence of the presentation follows the order in which the questions in the statement of the problem appear. The tables and graphs presented in this section were gathered from, the National Aeronautics Space Administration's presentation [5] on the vital signs of the planet under global climate change and Euro barometer Report [42].

Figure 1 shows the atmospheric carbon dioxide concentration in parts per million (ppvmv) from the year 2005 until present. It could be inferred from the graph that $\mathrm{CO}_{2}$ levels drastically increased over the recent years; from a 378 ppmv starting point in 2005, an 18 ppmv increment was evident for the seven-year period.

Figure 2 shows the global surface temperature of the Earth from year 1800 up to year 2010. "This graph illustrates the change in global surface temperature relative to 1951-1980 average temperatures. "Global surface temperatures in 2012 were the ninth warmest on record" [5], the gray bars on the graphs represent the uncer-

\section{DIRECT MEASURMENTS:2005-PRESENT}

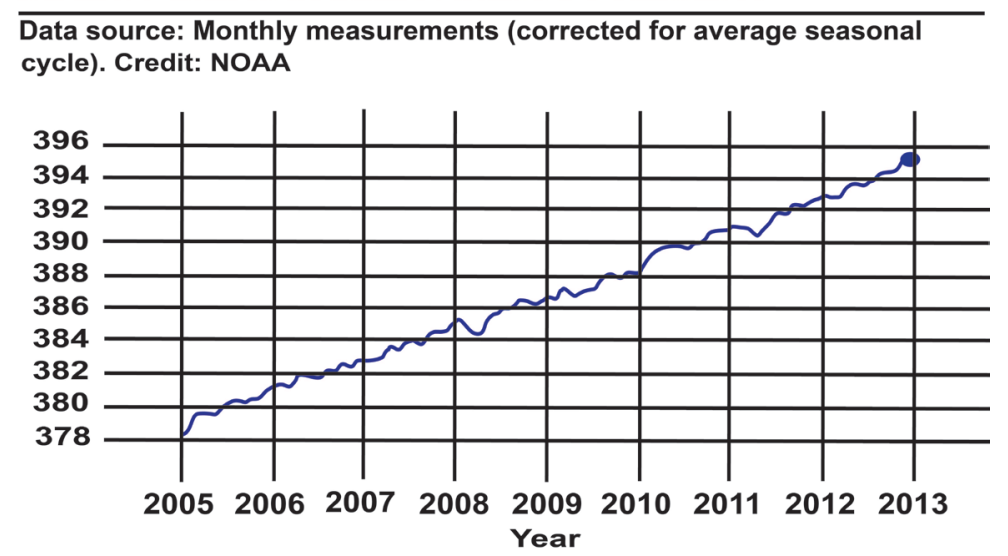

Figure 1. Carbon dioxide concentration. Source: National aeronautics and space administration [43]. 
tainty on the given measurements. However, these results could be considered as consistent with the ones prepared by the Climatic Research Unit.

Figure 3 shows the decline in the arctic sea ice levels for the year 1980 to present. "Arctic sea ice reaches its minimum each September. The graph above shows the average monthly arctic sea ice extent in September from 1979 to 2010, derived from satellite observations. The September 2010 extent was the third lowest in the satellite record" [43]

Figure 4 shows the decreasing amount of land ice over a period of time due to climate change. "Data from NASA's Grace Satellites show that the land ice sheets in both Antarctica and Greenland are losing mass. The continent of Antarctica (left chart) has been losing more than 100 cubic kilometers (24 cubic miles) of ice per year since 2002" [44]

Figure 5 shows the increasing sea levels over time brought about by climate change. National Aeronautics and Space Administration [5] explains that increase in sea levels could be brought about by the melting of land ice or the expansion of water volume as the surface temperature increases. "The chart on the left shows historical sea level data derived from coastal tide gauge records (trend calculated using the linear regression method). The chart on the right shows the average sea level since 1993 derived from global satellite measurements" [5].

Figure 6 shows the result of the study conducted by Eurobarometer Report among 16,000 European from February to April 2010. When respondents were asked what energy source would be least expensive in 50 years, $40 \%$ said that other renewables would be, followed by hydroelectric power (24\%), while $18 \%$ of the respondents did not know.

Figure 7 shows the views of the respondents which energy source will be most useful in 50 years. About $27 \%$ of the respondents said that it would be the renewables such as solar power, wind power, and geothermal; how-

\section{GLOBAL LAND-OCEAN TEMPERATURE INDEX}

Data source: NASA's Goddard Institute for Space Studies (GISS) This trend agrees with other global temperature records provided by the U.S. National Climatic Data Center, the Japanese Meteorological Agency and the Met Office Hadley Centre/ Climatic Research Unit in the U.K. Credit: NASA/GISS

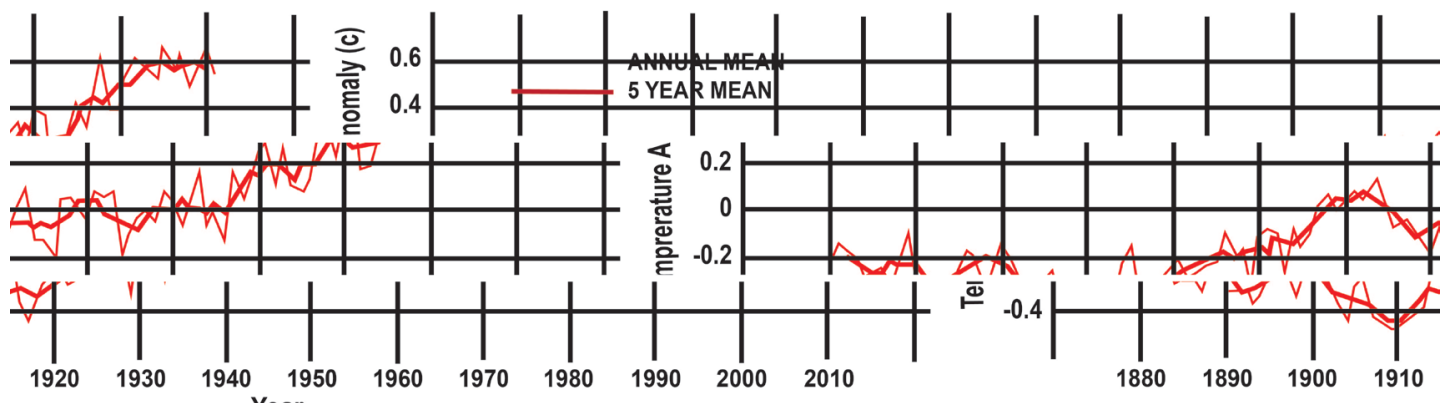

Figure 2. Global surface temperature, source: national aeronautics and space administration [5].

\section{AVERAGE SEPTEMBER EXTENT}

Data source: Satelite observations. Credit: NSIDC

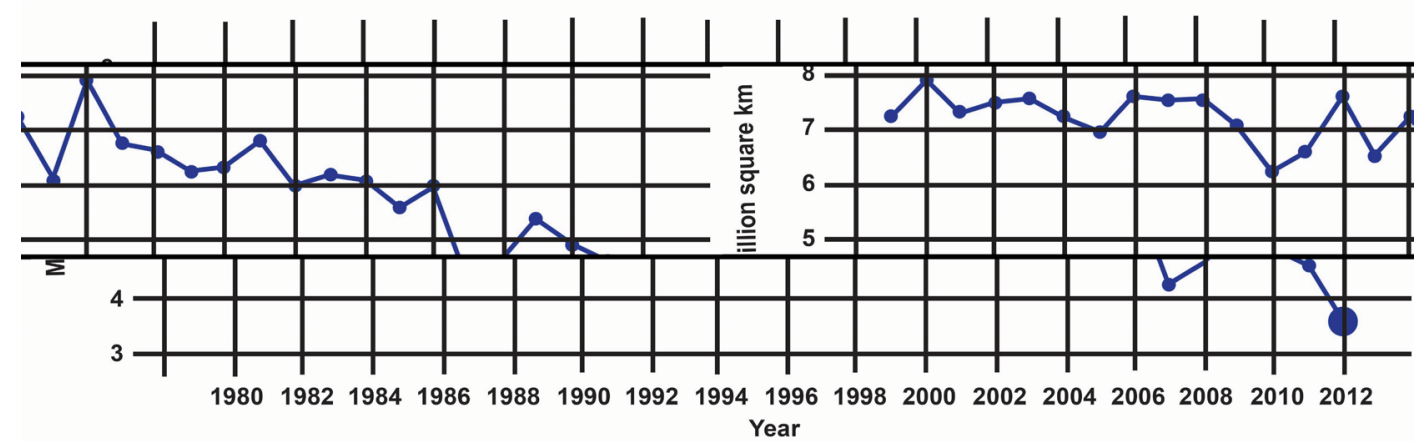

Figure 3. Artic sea ice, source: national aeronautics and space administration [43]. 


\section{ANTARCTICA MASS VARIATION SINCE 2002}

Data source: Ice mass measurment by NASA's Grace satellites. Credit: NASA/University of California

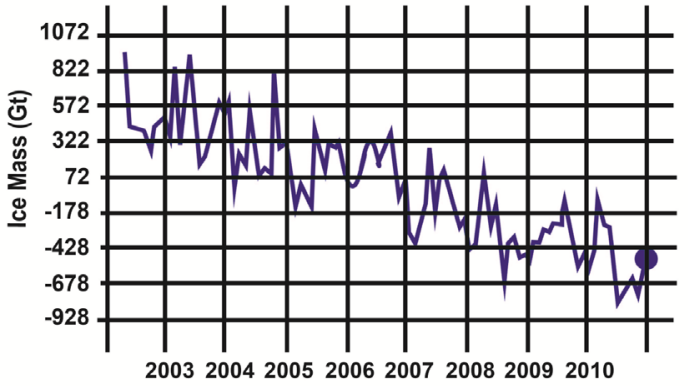
Year
GREENLAND MASS VARIATION SINCE 2002

Data source: Ice mass measurement by NASA's Grace satellites. Credit: NASA/University of California

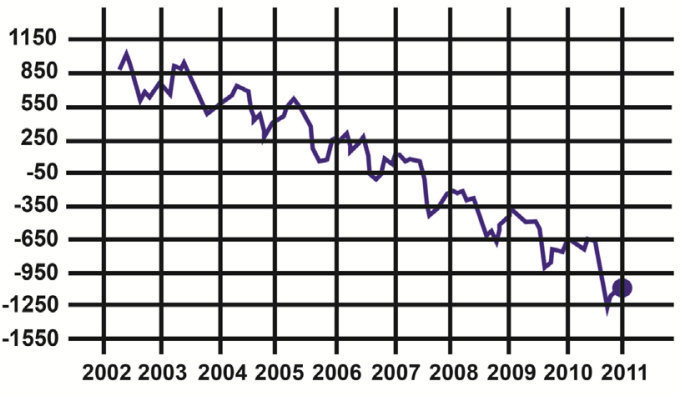

Year

Note: In the above charts, mass change is relative to the average during the entire period. (Reference)

Figure 4. Land ice, source: national aeronautics and space administration [43].



*estimate for 20 th century

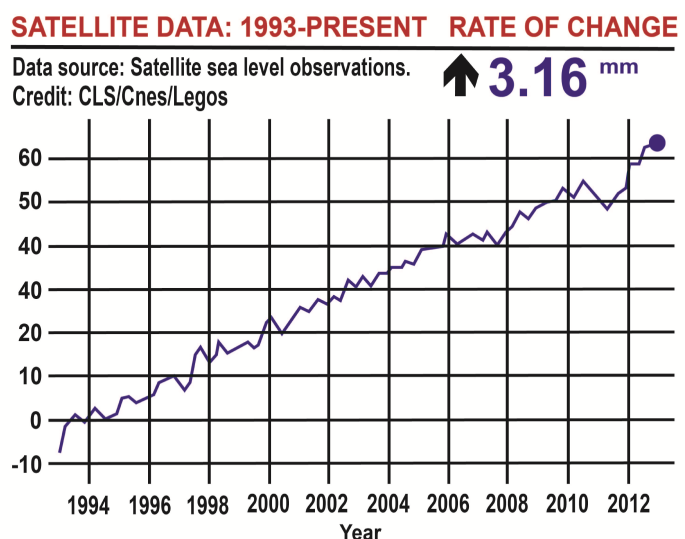

Inverse barometer applied and seasonal signals removed

Figure 5. Sea level, source: national aeronautics and space administration [5].



Figure 6. Energy resource that will be least expensive in 50 years, source: eurobarometer report, bimonthly magazine [42].

ever, 20\% did not know anything about energy sources or did not consider any energy source as useful for the next 50 years.

Figure 8 shows the views of the respondents regarding the energy source that will be best for the environment 
in the next 50 years. Still, a large number of respondents (67\%) said that it would be renewable energy sources such as solar power, wind power, and geothermal; $38 \%$ said that it would be hydroelectric power; while $14 \%$ of the respondents did not have any idea about it.

Figure 9 shows the responses of the respondents when asked about which energy source should be researched more. The majority of the respondents (51\%) said that it should be on cleaner transport.

Table 1 shows the environmental effects of solar power, wind power, and hydroelectric power. As discussed in the literature earlier, solar energy production causes cadmium deposits on ecosystems; wind power has an effect on birds and bat mortality within the wind farms; while hydroelectric power usually causes submersion of nearby grasslands.

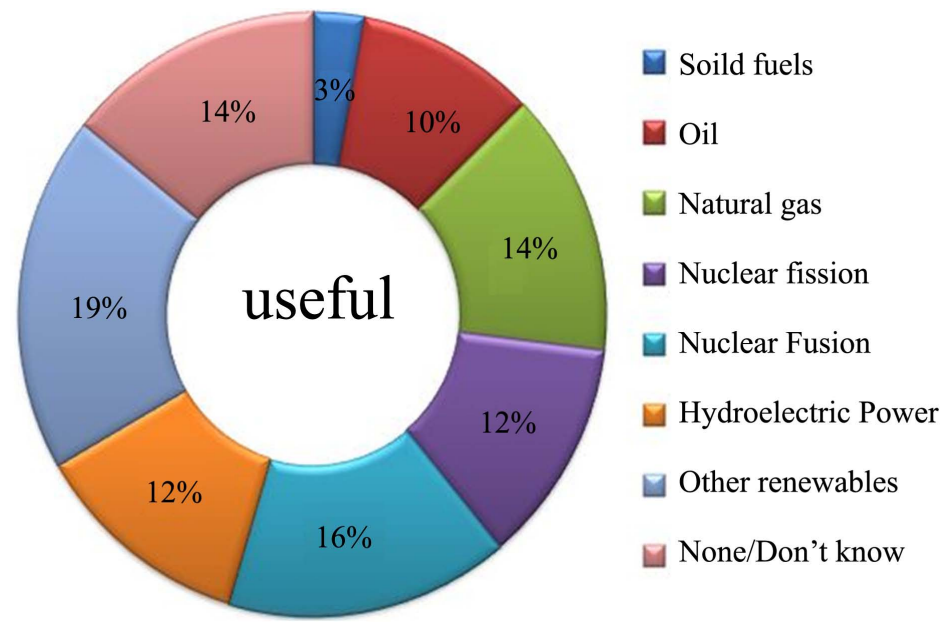

Figure 7. Energy resource that will be most useful in 50 years, source: eurobarometer report, bimonthly magazine [42].

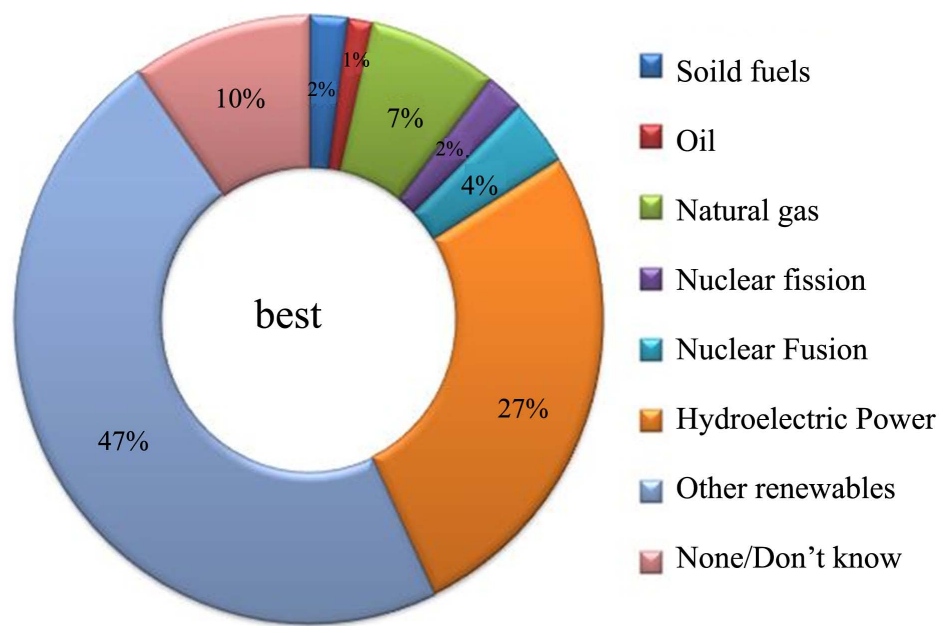

Figure 8. Energy resource that will be best for the environment in the next 50 years, source: eurobarometer report, bimonthly magazine [42].

Table 1. Environmental effects of renewable energy sources.

Renewable energy source

Solar energy

Wind power

Hydroelectric power
Environmental effects

Cadmium deposition

Birds and bats mortality

Submersion of grasslands 
Table 2 shows the profile of the respondents that served as a population for this research study. Of the 93 respondents, $47.31 \%$ of these were males while $52.68 \%$ were females. The age of the respondents varied from 20 - 35 (24.73\%), 36 - 50 (38.70\%), 51 - 65 (21.50\%) and above 65 (15.05\%). The years of experience in the field by the respondents was also evaluated. The majority of the respondents was in the field for 5 - 10 years already (44.08\%), followed by those who were practicing for $11-20$ years (31.18\%); those who were in the field for less than 5 years and those who were practicing for 20 years both composed $11.82 \%$ of the total sample population.

Figure 10 shows the responses of 93 respondents when asked what was the most efficient renewable energy source among hydroelectric, wind power, and solar energy, More than half of the respondents said that it was wind power (62\%), while $21 \%$ said it was hydroelectric, and $17 \%$ of the respondents said solar energy was the most efficient among the three.

Table 3 shows the computation of the significant relationship between the heritage site preservation and the use of renewable energy sources. The measure of heritage site preservation was based on NASA report on climate changes as shown by the previous figures above. The results show that there is no significant difference between the use of renewable energy resources and the preservation of heritage sites because the computed t-value did not exceed the tabular t-value. Therefore, the null hypothesis should be accepted.

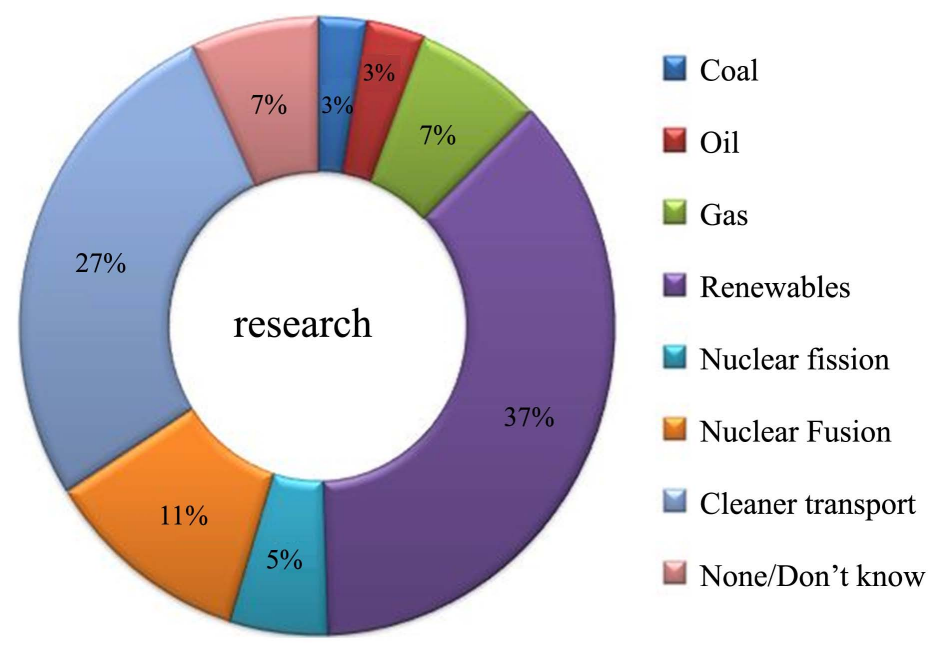

Figure 9. Area that should be researched more, source: eurobarometer report, bimonthly magazine [42].

\section{Most Efficient Renewable Energy}

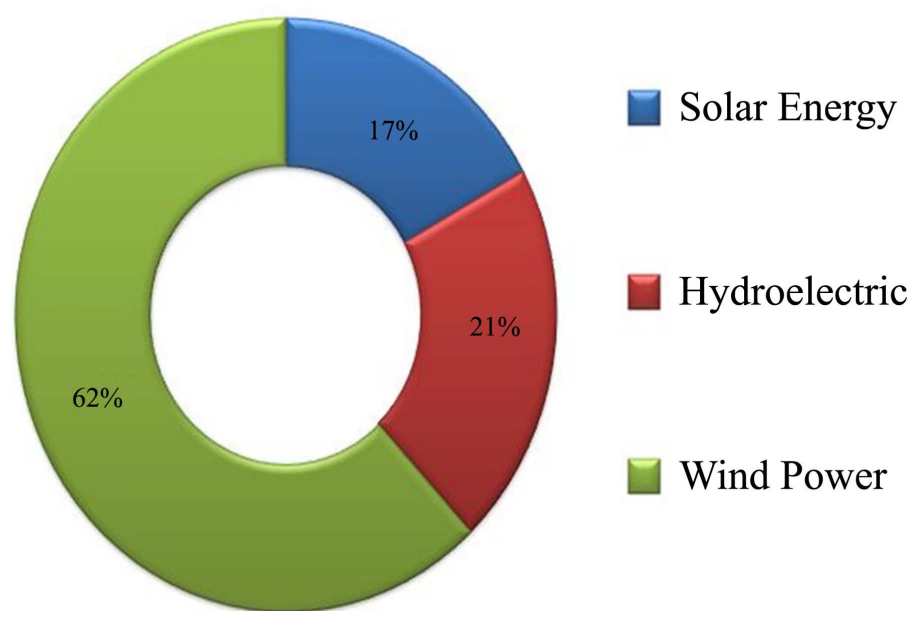

Figure 10. The most efficient renewable energy source. 
Table 2. Profile of the respondents.

\begin{tabular}{ccc}
\hline Profile variable & Total & Percentage \\
\hline Gender & & 47.31 \\
Male & 44 & 52.68 \\
Female & 49 & 24.73 \\
Age & & 38.70 \\
$20-35$ & 23 & 21.50 \\
$36-50$ & 36 & 15.05 \\
$51-65$ & 20 & 11.82 \\
Above 65 & 14 & 44.08 \\
Experience in the field & & 31.18 \\
$<5$ years & 11 & 11.82 \\
5 - 10 years & 41 & 29 \\
$11-20$ years & 11 & \\
$>20$ years & & \\
\hline
\end{tabular}

Table 3. Significant relationship between renewable energy sources.

\begin{tabular}{|c|c|c|c|c|c|c|}
\hline Variable & Computer r value & Degrees of freedom & Tabular t-value & Computed t-value & Decision & Interpretation \\
\hline $\begin{array}{c}\text { Heritage site } \\
\text { preservation } \\
\text { Renewable energy } \\
\text { sources }\end{array}$ & $\begin{array}{l}0.04 \text { no } \\
\text { relationship }\end{array}$ & 1 & 12.706 & 0.042 & Accept Ho & Not significant \\
\hline
\end{tabular}

\section{Conclusions}

- The climate may have been continually changing for the past thousands of years, but the effects of climate change and global warming on the arctic ice, carbon dioxide concentration, sea levels, global surface temperature, and land ice status are undeniable. These factors greatly contribute to the deterioration of the preservation of world heritage sites.

- Citizens are greatly aware of the effects of climate change and would prefer energy sources that are less expensive, helpful in the environment, and promote cleaner transport.

- Wind power is the energy source that has the least negative effect on the environment. Renewable energy sources that have least negative environmental effects should be promoted and built-up for greater use.

- The wind power is the most efficient renewable energy source among the three green energy sources provided in this research.

- There is no significant relationship between the use of renewable energy sources (e.g. solar power, wind power, and hydropower) and the preservation of world heritage sites.

- According to National Aeronautics and Space Administration reports [5], the current vital signs of the planet under global climate change include the decrease in arctic sea ice minimum to $12 \%$ per decade, increase in atmospheric carbon dioxide concentration to 393 parts per million, increase of sea level to $3.19 \mathrm{~mm}$ per year, increase of global surface temperature to $1.5 \mathrm{~F}$ since 1880, and the decrease of land ice to 100 billion tons per year.

- According to the survey results of Euro barometer Report among 16,000 respondents, renewable sources of energy such as solar power, wind power and geothermal (40\%) were considered to be the least expensive, the most useful (27\%), and the most helpful in the environment (67\%) among other energy sources in the next 50 years. More than half (51\%) of the respondents said that further research on clean transport should be done.

- The renewable sources of energy also have environmental effects. Solar energy production causes cadmium deposits on ecosystems; wind power has an effect on birds and bats mortality within the wind farms; while hydroelectric power usually causes submersion of nearby grasslands.

\section{Recommendation}

1) This study was limited by a case-study research design, and future research papers that would have the same 
interest could consider having the quantitative design in order to increase the generalizability of the results.

2) A bigger number of respondents should be utilized in the next research studies to establish a reliable data concerning climate change.

3) The deterioration of world heritage sites and the effect of climate mitigating measures on these should be highlighted in future studies.

4) Let the variables be widened i.e., extending the number of renewable energy sources being studied from three to four or more.

There should be a more objective measurement of climate change in the next research papers.

\section{References}

[1] UNESCO World Heritage Centre (2008) Policy Document on the Impacts of Climate Change on World Heritage Properties. United Nations Educational Scientific and Cultural Organization, World Heritage Centre. UNESCO, Paris.

[2] Zimmermann, G. and Vanderheiden, G. (2007) Accessible Design and Testing in the Application Development Process: Considerations for an Integrated Approach. Journal on Universal Access in the Information Society, 7, 117-128.

[3] Intergovernmental Panel on Climate Change (2002) Climate Change and Biodiversity. Terminal Paper V, IPCC.

[4] United Nations Framework Convention on Climate Change (1994) Full Text of the Convention.

[5] National Aeronautics and Space Administration (2013) What's in a Name? Global Warming vs. Climate Change. http://www.nasa.gov/topics/earth/features/climate_by_any_other_name.html

[6] Department of Ecology, Washington State (2012) Climate Change Education: What Is Climate Change? http://www.georgetownclimate.org/adaptation/state-information/overview-of-washingtons-climate-change-preparations

[7] Beniston, M. (2005) Climatic Change and Its Impacts: An Overview Focusing on Switzerland. Kluwer Academic Publishers, Dordrect.

[8] Fuglestvedt, J., Berntsen, T., Myhre, G., Rypdal, K. and Skeie, R.B. (2007) Climate Forcing from the Transport Sectors. Center for International Climate and Environmental Research-Oslo, 105, 454-458.

[9] Tamwoy, S.M. (2008) The Impact of Global Climate Change and Cultural Heritage: Grasping the Issues and Defining the Problem. Historic Environment, 21, 2-9.

[10] Bureau of Meteorology (2005) Climate Change. http://www.bom.gov.au/climate/change/

[11] UNESCO World Heritage Centre (2007) Climate Change Threatens UNESCO World Heritage Sites. UNESCO, Paris. http://unfccc.int/essential_background/convention/background/items/1349.php

[12] Demirbas, A. (2009) Political, Economic and Environmental Impacts of Biofuels: A Review. Applied Energy, 86, S108-S117.

[13] Morales, A. (2012) Wind Power Market Rose 41 GW in 2011. Business Week.

[14] National Renewable Energy Laboratory (2000) Solar through Power Plants. Department of Energy, Washington DC.

[15] Holm, A., Blodgett, L., Jennejohn, D. and Gawell, K. (2010) Geothermal Energy: International Market Update. US Department of Energy Geothermal Technologies Program, Washington DC.

[16] Environmental Protection Agency (2012) Climate Change Basics. http://www.epa.gov/climatechange/basics/

[17] Seiz, G. and Foppa, N. (2007) The Activities of the World Glacier Monitoring Service. World Glacier Monitoring Service, Zurich.

[18] Dyurgerov, M. (2005) Glacier Mass Balance and Regime Measurements and Analysis, 1945-2003. Institute of Arctic and Alpine Research, University of Colorado, Boulder.

[19] National Snow and Ice Data Center (2013) State of the Cryosphere: Sea Ice. http://nsidc.org/cryosphere/sotc/sea ice.html

[20] Dominic, F., Burns, S., Neff, U., Mudulsee, M., Mangina, A. and Matter, A. (2004) Palaeoclimatic Interpretation of High-Resolution Oxygen Isotope Profiles Derived from Annually Laminated Speleothems from Southern Oman. Quaternary Science Reviews, 23, 935-945. http://dx.doi.org/10.1016/j.quascirev.2003.06.019

[21] Adams, J. and Faure, H. (1997) Review and Atlas of Palaeovegetation: Preliminary Land Ecosystem Maps of the World since the Last Glacial Maximum. Oak Ridge National Laboratory, Oak Ridge.

[22] Heogh-Guldberg, O. (2004) Marine Ecosystems and Climate Change Chapter 20. In: Lovejoy, L.T. and Hannah, L.J., Eds., Climate Change and Biodiversity, Yale University Press, New Haven.

[23] London Climate Change Partnership (2002) Climate Change Impacts in a London Evaluation Study. Greater London Authority, London. 
[24] REN21 (2010) Renewables 2010 Global Status Report. Renewable Energy Policy Network for the 21st Century.

[25] Al-Zubaidy and Kaddory, M.S. (2015) A Literature Evaluation of the Energy Efficiency of Leadership in Energy and Environmental Design (LEED)-Certified Buildings. American Journal of Civil Engineering and Architecture, 3, 1-7. http://dx.doi.org/10.12691/ajcea-3-1-1

[26] Molina, M., Zaelke, D., Sarmac, K., Andersen, S., Ramanathane, V. and Kaniaruf, D. (2009) Reducing Abrupt Climate Change Risk Using the Montreal Protocol and Other Regulatory Actions to Complement Cuts in $\mathrm{CO}_{2}$ Emissions. Proceedings of the National Academy of Sciences of the United States of America, 106, 20616-20621. http://dx.doi.org/10.1073/pnas.0902568106

[27] Stern, N. (2007) Stern Review on the Economics of Climate Change: Part III: The Economics of Stabilisation. H.M. Treasury, London.

[28] Alsema, E., Wild-Scholten, M.D. and Fthenakis, V. (2006) Environmental Impacts of PV Electricity Generation-A Critical Comparison of Energy Supply Options. 21st European Photovoltaic Solar Energy Conference and Exhibition, Dresden, 4-8 September 2006.

[29] Baker, L. (2012) Brief History of Windmills in the New World. Windmillers' Gazette.

[30] BTM. C (2010) Wind of Energy by 2013.

[31] Millborrow, D. (2009) Is Wind Power Reliable?-An Authoritative Article from David Millborrow Who Is Technically Experienced and Numerate, Unlike Many Other Commentators. http://www.claverton-energy.com/is-wind-power-reliable-an-authoritative-article-from-david-millborrow-who-is-techn ically-experienced-and-numerate-unlike-many-other-commentators.html

[32] RSPB (2005) RSPB: Wind Farms. http://www.rspb.org.uk/ourwork/policy/windfarms/index.aspx

[33] Iuga, D. (2010) The Social Acceptance of Wind Energy: An Introduction to the Concept. European Wind Energy Association, Brussels.

[34] Water Encyclopedia Science and Issues (2010) Hydroelectric Power-Dam, Building, River, Percentage, Largest, Hydro, System, Plants, Source, Human, Pacific. http://www.waterencyclopedia.com/Ge-Hy/Hydroelectric-Power.html

[35] The Electricity Forum (2008) Hydro Electricity Explained. http://www.electricityforum.com/hydroelectricity.html

[36] Robbins, P. (2007) Hydropower. Encyclopedia of Environment and Society.

[37] Şentürk, F. (1994) Hydraulics of Dams and Reservoirs. Water Resources Publications, Highlands Ranch.

[38] Atkins, W. (2003) Hydroelectric Power. Water: Science and Issues, 2, 187-191.

[39] Urband, F. and Mitchell, T. (2011) Climate Change, Disasters and Electricity Generation. Institute of Development Studies, Brighton.

[40] Al-Zubaidy, M.S.K. (2014) Optimizing the Risk-Preparedness and Disaster Management Systems of All World Heritage Sites by Exploiting HPWS and Conform to the UNESCO Guidelines. American Journal of Civil Engineering and Architecture, 2, 177-185. http://dx.doi.org/10.12691/ajcea-2-6-1

[41] Bromley, D.B. (1999) Academic Contributions to Psychological Counseling. 2. Discourse Analysis and the Formulation of Case-Reports. Counseling Psychology Quarterly, 4, 75-89. http://dx.doi.org/10.1080/09515079108254431

[42] Eurobarometer Report (2002) A Summary of Opinion Surveys on Wind Power. Bimonthly Magazine.

[43] National Aeronautics and Space Administration (2012) NASA Finds 2011 Ninth-Warmest Year on Record. http://www.nasa.gov/topics/Earth/features/2011-temps.html

[44] National Aeronautics and Space Administration (2012) NASA Finds 2012 Sustained Long-Term Climate Warming Trend. http://www.nasa.gov/topics/Earth/features/2012-temps.html 